\title{
A MAGYARORSZÁGI GAZDÁLKODÓ SZERVEZETEK SZOFTVERKÖRNYEZETÉNEK EMPIRIKUS VIZSGÁLATA
}

\author{
Horváth Ádám Béla
}

\begin{abstract}
Absztrakt: Ez a tanulmány egy kérdőíves felmérés eredményeire támaszkodva azt a kérdést vizsgálja, hogy a magyarországi gazdálkodó szervezetek üzleti tevékenységei milyen mértékben támogatottak különböző szoftveres megoldásokkal. A beérkezett 498 válasz egymástól jelentős mértékben eltérö mintázata és a szoftver-környezet egyes elemei között mutatkozó relatív alacsony korrelációja egy olyan, új értékelési rendszer kialakítását tette szükségessé. Az új elemzési eljárás képes az egyes gazdálkodó szervetek által rendszeresített szoftver-környezeteket a korábbi kutatásokban tapasztaltaknál részletesebben elemezni, de robosztus marad a válaszokban mutatkozó jelentős különbségekre. A korábban publikált elméleti eredményekre, valamint a kvantitatív kutatásokban bemutatott eljárások tapasztalataira építve ez az elemzési módszertan a feltáró faktorelemzésen (EFA) és a részben arra épülő konfirmatív faktorelemzésen (CFA) alapul. A kutatásomban igazolódott, hogy ezen mutatószám-rendszer be tudja tölteni más modellekben a magyarázó-változó szerepét, így objektív módon, kvantitatív eszközök segítségével mérhetővé vált az IKT-infrastruktúra az azt üzemeltető gazdálkodó szervezetekre gyakorolt hatása.
\end{abstract}

\begin{abstract}
Based on the results of a questionnaire survey, the aim of this research is to investigate the extent to which the business activities of the for-profit organizations in Hungary are supported by various software solutions. The significantly different pattern of the 498 responses received and the relatively low correlation between each element of the software environment made necessary the development of a new evaluation system. The new method of analysis procedure can analyse the software environments for-profit organizations in Hungary more sophistically than in previous research, but it is robust for significant differences in the received answers of the questionnaire. Based on previously published theoretical results and methods used in quantitative research, this analytical methodology is based on the methods of exploratory factor analysis (EFA) and confirmatory factor analysis (CFA). The research proved that this system of indicators can fulfil the role of an explanatory variable in other models, so the impact of the software-environment of the ICT infrastructure of the for-profit organizations in Hungary on their operators can be measured in an objective way, by using the quantitative tools.
\end{abstract}

Kulcsszavak: Üzleti folyamatok, IKT-környezet, integrált megoldások, szigetszerü megoldások, empirikus kutatás.

Keywords: Business processes, ICT-infrastructure, integrated solutions, isolated applications, empirical research.

\section{Bevezetés}

Ernst Tiemeyer (2020) könyvében bemutatja, miképpen alakult át a gazdálkodó szervezetek életében az infokommunikációs-infrastruktúra (IKT-infrastruktúra) által betöltött szerep az elmúlt évtizedekben. Az 1970-es évek végéig az IKTinfrastruktúra fó feladatának az információ-feldolgozás racionalizálását tekinthetjük, viszont az elkövetkező évtizedekben az IKT-infrastruktúra bővülő szolgáltatásai (például az üzleti folyamatok támogatása munkafolyamat-szabályozás (workflow) segítségével) hatékonyabbá tették a vállalatok üzleti folyamatainak lebonyolítását. Az 1990-es évek második felében az online lehetőségek elterjedésével (webshopok, online termékek és szolgáltatások) az IKT-infrastruktúra szolgáltatásai az értékteremtés és értékesítés lehetséges új, de nem kizárólagos színterévé léptek elő. 
Az IKT-infrastruktúra tág, és teljesen pontosan körül nem határolt fogalom. Jelen publikációmban a fogalom Kordha et al. (2011) általi értelmezésére támaszkodom, amely alapján ebbe a fogalomkörbe tartozik minden, az adatok gyüjtésére, tárolására, visszakeresésre, ábrázolásra és továbbítására szolgáló materiális (hardver), valamint immateriális (szoftver) infokommunikációs megoldás, továbbá az ezek müködtetéséhez szükséges más infrastrukturális elemek összesége.

Ahhoz, hogy megvizsgálhassuk az IKT-infrastruktúra vállalatokra gyakorolt hatását, többféle megközelítést alkalmazhatunk: Michael E. Porter (1985) alkotta meg az első olyan, a gazdálkodó szervezetek felépítését leképező modellt, amely modell az IKT-infrastruktúrát már a vállalati környezet integráns részének tekintette (értéklánc-modell). Az értéklánc-modellben a vállalatok müködése több egymástól független, de egymással kapcsolatban álló tevékenységként kerültek értelmezésre. $\mathrm{Az}$ előbb említett független tevékenységeket Porter két fő csoportra osztotta (elsődleges, valamint támogató tevékenységek). Az értéklánc-modellben a vállalati IKT-infrastruktúra kizárólag a támogató tevekénységek között kapott helyet. Az IKT-infrastruktúra, illetve az általa nyújtott szolgáltatások modellben betöltött szerepe az azóta bekövetkezett technológiai fejlödés és az ebböl fakadó szerepbővülés ellenére sem változott meg (Porter et al., 2014). Így Porter nem vette figyelembe, hogy az elsődleges tevekénységek körébe tartozó gyártási folyamatokat miképpen alakította át a számítógéppel támogatott gyártás (CAM) körébe tartozó különböző megoldások elterjedése (Hoque et al., 2001). Ezen változások eredményeképpen az emberi közremüködés szükségességét részben vagy egészben felváltotta a gyártási és/vagy szolgáltatási folyamatok automatizált vezérlésének lehetősége.

Számos kísérlet történt az értéklánc-modell kiegészítésére és módosítására. Meier-Stormer (2012) szerzőpáros változata több ponton jelentett elörelépést. Egyrészt elismerték az IKT-infrastruktúra szerepét nemcsak a támogató, hanem az elsődleges tevékenységek körében is, valamint az IKT-infrastruktúra szolgáltatásportfoliója mellett az információbiztonsági szempontok is hangsúlyos szerepet kaptak. Modelljük hátránya azonban, hogy kizárólag csak a digitális termékeket és szolgáltatásokat elóállító szervezetek esetében alkalmazható kompromisszumok nélkül. Nagy et al. (2018) munkájukban az értéklánc-modell eredeti változatának egyes tevékenységei bővültek ki az Ipar 4.0 körében értelmezett informatikai megoldásokkal. Ezáltal láthatóvá vált, hogy az adatgyüjtésre, illetve a távolról vezérelhető és/vagy automatizált döntéshozatalra képes gépek miképp alakítják át a gazdálkodó szervetek értékteremtő folyamatait. Összehasonlítva a nemzetközi szakirodalommal, ez tekinthető a legteljesebb modellnek, amely reflektál a technológiai fejlődés eredményeire, és ennek következményeként az IKTszolgáltatások a támogató és elsődleges folyamatokban betöltött egyre jelentősebb szerepére. Tudományos publikációkban a most bemutatott modellekkel, mint elméleti megközelítésekkel találkozhatunk, az irodalom-kutatás során nem került látókörbe olyan kvalitatív vagy kvantitatív kutatás, amely szemléletében a Porterféle értéklánc-modellre, vagy annak valamely módosított változatára épült volna. 
Gyakorlati szemléletü az IEEE (N. A.) által kifejlesztett EITBOK 4-, illetve annak kibővített, 5-rétégü BIAT-modellje, amelyhez hasonló elméleti megközelítést alkalmazott Hasselbring (2000) és Suosa et al. (2010) munkájukban is. Ez a megközelítés abból indul ki, hogy a vállalat müködését négy szintre lehet felosztani, mégpedig az üzleti folyamatok, (üzleti) információk, szoftver-alkalmazások, és a technológiai háttér rétegei. A technológiai háttér rétege az ötszintủ modellben kettéválik a szoftver- (például: operációs-rendszerek, adatbázis-szerver, virtualizációs környezet stb.) és a hardver-infrastruktúrára. Ez a kutatási megközelítés azért is tekinthető jelentősnek, mert elméleti modellalkotás szintjén Park et al. (2008) az elöbbiekben tárgyalt rétegek tükrében bemutatja a releváns kockázatokat, és ezzel összhangban a bevezetésre javasolt információbiztonsági eljárásokat és megoldásokat. A Porter-féle értéklánc-modellel kapcsolatban elmondottakhoz hasonlóan az irodalomkutatás során nem sikerült azonosítani olyan kvalitatív vagy kvantitatív kutatást, amely elméleti megalapozottságában 4- vagy 5rétegü BIAT-modellre támaszkodott volna.

A korábban bemutatott elméleti modellek ellenpontjaként értelmezhetőek azok a keretrendszerek, amelyek különböző aspektusból elemzik a gazdálkodó szervezet és az alkalmazott technológia kölcsönhatását. Ezekre a keretrendszerekre alapozva különféle leíró- vagy következtetéses statisztikai eljárások felhasználásával kvalitatív vagy kvantitatív módon (Oliveira-Martins, 2011) elemzik az IKTkörnyezet, vagy annak valamelyik részterülete által kifejtett hatásokat. A keretrendszerek közül a kettő leggyakrabban használt a Davis (1989) Technológia Elfogadási Modellje (Technology Acceptance Modell - TAM; Keszey et al., 2017), amely azt vizsgálja, hogy egy szervezeten belül az IKT-eszközök használata során szerzett tapasztalatok alapján hogyan viszonyulnak egy új technológia alkalmazásához. A kutatásokban szintén gyakran alkalmazzák a Technology Organization - Environment keretrendszert (TOE), amely külső és belsö körülmények hatásainak tükrében vizsgálja a szervezeti innovációs hajlandóságot (Awa et al., 2016).

A doktori kutatásomban azt a kérdéskört vizsgálom meg, hogy a Magyarországon müködő gazdálkodó szervezetek által használt IKT-infrastruktúra milyen mértékben járul hozzá az őket üzemeltető szervezetek eredményességéhez, valamint versenyképességéhez, illetve az IKT-környezet fejlettsége milyen mértékben áll összhangban információbiztonsági szempontok érvényesülésével (Chang et al., 2006). A doktori kutatás most bemutatott részkutatásában egy olyan, a fent bemutatott modelleken és keretrendszereken alapuló mutatószám-rendszert alakítok ki, amely képes reprezentálni egy adott vállalat által használt szoftverkörnyezetet, és be tudja tölteni a TOE- vagy a TAM-keretrendszerre alapuló elemzési célú modellekben a magyarázó változó szerepét. Ezek a modellek képesek a Magyarországon bejegyzett vállalatok információbiztonsági szintjét az IKTinfrastruktúra fejlettségének tükrében vizsgálni. 


\section{A kutatás elméleti keretei}

A vállalati IKT-infrastruktúra vizsgálatának szoftverkörnyezet irányából történő megközelítése azért indokolt, mert a szoftverkörnyezet logikája és a vállalat által kialakított üzleti folyamatok mindenkori összhangja kulcskérdése az IKTinfrastruktúra értékteremtő képességének (Pereira-Suosa, 2005; Aversano, 2012). Ennek a szemléletnek megfelelően a most bemutatott rész-kutatásban csak az üzleti szempontból releváns alkalmazásokkal foglalkozom, kizárom az 5-rétegü BIAS modell alapján a rendszer-szoftverek körébe sorolható elemeket.

A vállalati alkalmazási környezet fejlödésének tekintetében fontos röviden áttekinteni az utolsó negyedévszázadban végbemenő, a MRP-II korszaktól kezdődő és napjainkig tartó fejlődését. Amennyiben a különböző megoldás-szállítók fejlesztéseit vizsgáljuk, a legfontosabb trend, hogy a különböző vállalatirányítási rendszerek törekednek a teljes vállalati tevékenységi kör lefedésére. Figyelembe kell venni azt a körülményt is, hogy az egyes rendszerek moduláris szerkezete, illetve az egyes vállalatirányítási rendszer alapját jelentő üzleti logikai réteg a különböző megoldásokban egymástól jelentős mértékben eltérnek. Az elözőekben láthattuk, hogy a vállalat-irányítási rendszerek szolgáltatásai napjainkra meghaladták az adatfeldolgozási feladatok kereteit. Legkésőbb a számítógép által támogatott tervezéshez (CAD) és termelésirányításhoz (CAM) kapcsolódó megoldások elterjedése gyökeresen átalakította a vállalati értékteremtési folyamatot az emberi beavatkozás szükségességét minimális szintre csökkentő automatizált müködés révén. Ezzel a folyamattal párhuzamosan a vállalati információs-rendszerek a korábban kialakult szigetszerü megoldások integrálásának igényével lépnek fel, elérve az alkalmazás portfólió homogénebbé válását. A szolgáltatás-orientált architektúra (SOA) kezdeti céljai közé tartozott az egyes szigetszerü-megoldások integrációja az alkalmazás-portfólió teljes lecserélése nélkül (Mulesoft, N. A.; QuistAphetsi-Kayode, 2013), amennyiben az érintett alkalmazások SOA-kompatibilisek, vagy alkalmazásprogramozási felületek (API) segítségével (Coldeway, 2007) azzá tehetők.

Amikor a gazdálkodó szervezetek által üzemeltetett szoftver-környezetet vizsgáljuk, a különböző kutatások alapján a következő kép tárul elénk: egyrészről bár kínálati oldalon - mint láttuk - elméletileg adottak a lehetőségek az integrált, a vállalat teljes tevekénységét nagyrészben vagy teljesen lefedő rendszer bevezetésére. Ezzel szemben a vállalatok rendszerint megmaradnak a szigetszerü megoldások alkalmazása mellett, és sokszor valamilyen külső kényszerítő tényező hatására (például: 2000-es év problémája, euró bevezetése stb.) indulnak el egy integrált rendszerre való átállás útján (Themistocleous, et al. 2001; Møller, 2003; Yahaya et al., 2004). A korábban publikált kutatások rámutattak továbbá arra a jelenségre is, hogy nem ritka több vállalatirányítási-rendszer egymással párhuzamos használata, még akkor is, ha ezek a rendszerek müködésük logikájában jelentős eltérést mutatnak (Michelberger, 2003). Több hazai és nemzetközi kutatás arra is rámutatott, hogy ritkán fordul elö, hogy egy vállalatirányítási-rendszer mindegyik modulját használnák (Alves et al., 2003; Drótos-Martos, 2012). Ebből az következik, hogy a vállalati szoftverkörnyezet-portfólió egy-egy integrált vállalatirányítási-rendszer 
mellett több szigetszerü megoldást is magában foglal. Ezért nem elégséges csupán a vállalatirányítási-rendszerek meglétét és annak hatásait vizsgálni, hanem ezen túllépve a teljes szoftver-környezetet érdemes elemezni és értékelni. A korábbi kutatások alapján azzal is számolni kell, hogy a kis- és középvállalkozások IKTinfrastruktúrával kapcsolatos beruházásaik során gyakran egyoldalúan az IKTmegoldásokból származó lehetséges üzleti előnyökre koncentrálnak. Így háttérbe szorulnak az IT-biztonsággal foglalkozó kérdések, és nem kielégítő módon foglalkoznak az IT-management stratégiai jellegü kérdéseivel (Park et al., 2008).

Bár a vállalatirányítási-rendszerek első generációjának kialakulása óta közel három évtized telt el, ezen rendszerek vállalatra gyakorolt hatása mind a mai napig vizsgálat tárgya. Napjainkban a kutatások és vizsgálatok aktualitásának egyik fő oka, hogy a vállalati információs architketúrát két forradalmi változás érte. Az egyik ezek közül a felhö-alapú megoldások egyre szélesebb körü elterjedése, és ezalatt nem kizárólagosan a szoftver mint szolgáltatásokat (SaaS) kell érteni. A kutatások és vizsgálatok aktualitásának másik oka a gazdálkodó szervezetek IKTinfrastruktúrájának az emberi beavatkozás nélküli adatgyüjtésre és távoli vezérlés segítségével müködni képes, a termelésben- és/vagy adminisztrációban közremüködő (IoT-megoldások) eszközökkel történő egyre szélesebb körü bövülése. Ezek az eszközök kiegészülhet akár mesterséges intelligencia-alapú döntéshozatali képességgel is. Mindkét forradalmi változás jelentős mértékben épít az integrált vállalatirányítási-rendszerek jelenlétére (Madjid et al., 2020) és centralizáló hatására (Masood-Sonntag, 2020). Ezen forradalmi változások jelentős mértékben átalakítják az olyan, eddig nem technológia-intenzívnek gondolt iparágak ellátási láncait is, mint például a faipar (Müller et al., 2019) vagy az élelmiszeripar (Ramundo et al., 2016). A kutatásom ezen ismeretekre alapuló átfogó modelljét a következö, 1. ábrán foglalom össze.

1. ábra: A kutatás áttekintő modellje

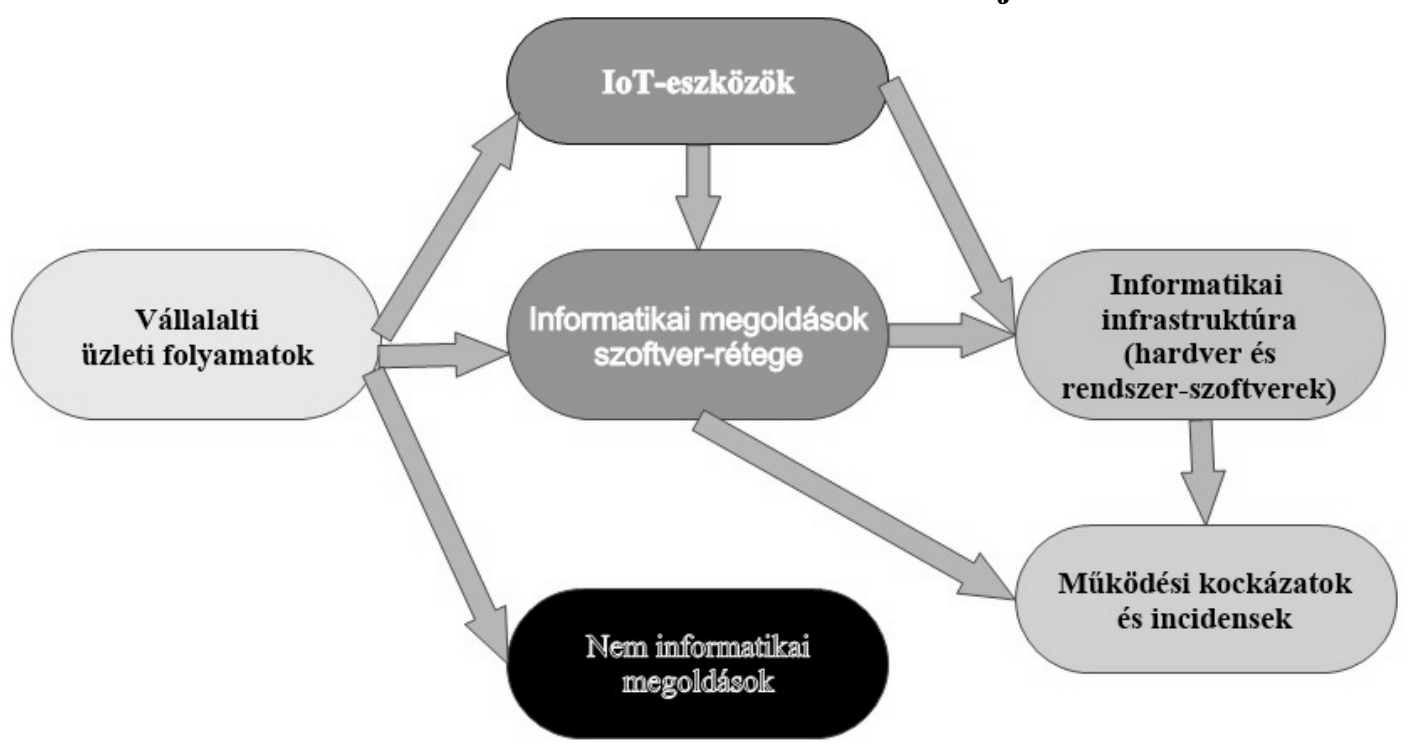

Forrás: A szerző saját szerkesztése 
A kutatásomban feltételezem, hogy a válaszadóknak van valamilyen formalizált vagy nem formalizált formában jelenlévő üzleti folyamata. Ezeket az üzleti folyamatokat támogatja valamilyen mértékben az adott gazdálkodó szervezet által üzemeltetett IKT-infrastruktúra által nyújtott szolgáltatások összessége. A most bemutatott részkutatásban a következő kutatási kérdésekre keresem a választ:

- Milyen mértékben támogatottak a válaszadók üzleti tevékenységei valamilyen szoftveres megoldással?

- A magyarországi gyakorlatra inkább az integrált rendszerek alkalmazása vagy a szigetszerü megoldások elterjedése a jellemző?

- Képezhetö-e olyan mutatószám vagy mutatószám-rendszer, amely képes reprezentálni a válaszadók által üzemeltetett szoftver-környezetet, és ezáltal mérhetővé válik az IKT-infrastruktúra gazdálkodó szervezetre gyakorolt hatása?

\section{A kutatás és eredményei}

A bemutatásra kerülő kvantitatív kutatás alapjául egy online kérdőíves lekérdezés keretében lebonyolított adatfelvétel eredményeképpen előállított adatbázis szolgál. A kérdőív első változatának elkészülte után sor került próba-kitöltetésre, és a visszajelzések alapján több (információbiztonsággal kapcsolatos) kérdést ki kellett törölni a kérdőívből, így alakult ki a kérdőív végleges változata, amelyben 11 kérdést tettem fel. 6 kérdést bontottam további alkérdésekre, így a válaszadóknak mindösszesen 75 kérdésre kellett választ adniuk. A kutatásban való részvételre ún. "hideg-hívások" útján olyan gazdálkodó szervezeteket kerestem meg, akik klasszikus termelö és/vagy szolgáltató tevékenységet is folytatnak. A leendő válaszadók kiválasztásakor szempont volt, hogy az utolsó két naptári évben legyen érvényes benyújtott beszámolója, mert így képezhetőek statikus és dinamikus mutató-számok is. A két év folyamatos müködés alapján feltételezhető továbbá, hogy kialakult valamilyen állandósult üzleti folyamatokból álló üzletviteli struktúra. A kérdőív nem volt anonimizált, így a kitöltött kérdőívekre adott válaszokból felépített adatbázis kiegészíthetőek a pénzügyi/számviteli beszámolók adataival is.

Tekintettel az erőforrásbeli korlátokra, úgy szerkesztettem meg a kérdőívet, hogy arra lehetőleg egyetlen vezető beosztású személy is választ tudjon adni. Az online kérdőív rendszer (LimeSurvey) beállításai lehetővé teszik, hogy a kérdéseket ne lehessen megválaszolatlanul hagyni, így biztosítható volt, hogy a kérdőív összes kérdése megválaszolásra kerüljön. Emiatt nagyon sok félbehagyott, részleges kitöltés történt, 1 teljesen kitöltött kérdőívre nagyságrendileg 3-4 félbehagyott kérdőív jutott. Közvetlenül közel 22000 vállalattal vettem fel a kapcsolatot, és összesen 498 értékelhető válasz érkezett. A lekérdezés befejezését követően a válaszokat egy táblázatkezelő szoftverrel készítettem elő statisztikai elemzésre és a kereszttáblás lekérdezésekhez. A további statisztikai elemzések során az R keretrendszerét (ver. 4.0.3) és annak több modulját (lavaan ver. 0.6-7 és psych ver. 2.0.12) használtam.

A válaszadók által 2017-ben a magyar számviteli szabályok szerint benyújtott beszámolóik alapján megvizsgáltam a kutatásban résztvevő gazdálkodó szervezetek 
mérleg-föösszeg és létszám-adatok alapján vett eloszlását. (Három válaszadó csak IFRS alapján készít beszámolót, így az ő adataik nem voltak elérhetőek az általam használt adatbázisokban.) A válaszadók mérlegföösszege és létszámadatok alapján történt besorolását az 1. táblázatban mutatom be:

1. táblázat: A válaszadók eloszlása mérlegföösszeg és létszám alapján

\begin{tabular}{|c|c|c|c|c|c|c|c|}
\hline & \multicolumn{6}{|c|}{ Mérlegföösszeg } \\
\hline & & $\begin{array}{l}1 \mathrm{Mft} . \\
\text { alatt }\end{array}$ & $\begin{array}{l}1 \mathrm{MFt}- \\
10 \mathrm{Mft}\end{array}$ & $\begin{array}{l}10 \mathrm{MFt}- \\
25 \mathrm{MFt} .\end{array}$ & $\begin{array}{l}25 \mathrm{Mft}- \\
100 \mathrm{Mft} .\end{array}$ & $\begin{array}{l}100 \mathrm{MFt} \text {. } \\
\text { felett }\end{array}$ & Össz. \\
\hline \multirow{5}{*}{ 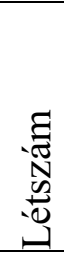 } & 10 fó alatt & 90 & 4 & 0 & 0 & 0 & 94 \\
\hline & 11-50 fö & 211 & 41 & 0 & 0 & 0 & 252 \\
\hline & 50-250 fö & 30 & 87 & 5 & 3 & 1 & 126 \\
\hline & 250 fö felett & 1 & 10 & 10 & 2 & 0 & 23 \\
\hline & Összesen & 332 & 142 & 15 & 5 & 1 & 495 \\
\hline
\end{tabular}

Forrás: A szerző saját szerkesztése

Látható, hogy mindkét dimenzió mentén baloldali aszimmetria mutatható ki, a kutatási eredményeket vélhetően nagyban befolyásolhatta, hogy az alacsony mérlegföösszeggel bíró gazdálkodó szervezetek jelentősen túlreprezentáltak.

A válaszadók iparági besorolására nem került sor, mert nem volt elérhető olyan adatbázis, amely megbízhatóan egy vagy több iparágba sorolta volna az egyes vállalkozásokat. A szúrópróba-szerü vizsgálatból pedig arra a következtetésre kellett jutnom, hogy a cégkivonatban szereplő tevékenységi körök (TEÁOR-számok) alapján nem lehet megbízhatóan a válaszadókat egy, vagy több iparágba sorolni. $A$ jelen tanulmányban bemutatott részkutatásba a kérdöivböl a következö kérdéseket vontam be (2. táblázat):

\section{2. táblázat: Kivonat a kutatás alapjául szolgáló kérdőívből}

B1. Használják a következő informatikai megoldásokat az Önök vállalatában?

$$
\text { Használunk Kiszervezve Nem Nem }
$$
használunk releváns

Csoportmunka-támogató

(naptár, teendők, e-mail) alkalmazás: groupware Raktárkészlet-nyilvántartó / nyersanyag-gazdálkodás Könyvviteli alkalmazás Tervezést támogató szoftver (CAD)

Kreatív alkalmazások: Photoshop kiadványszerkesztő / filmvagy hangszerkesztő 


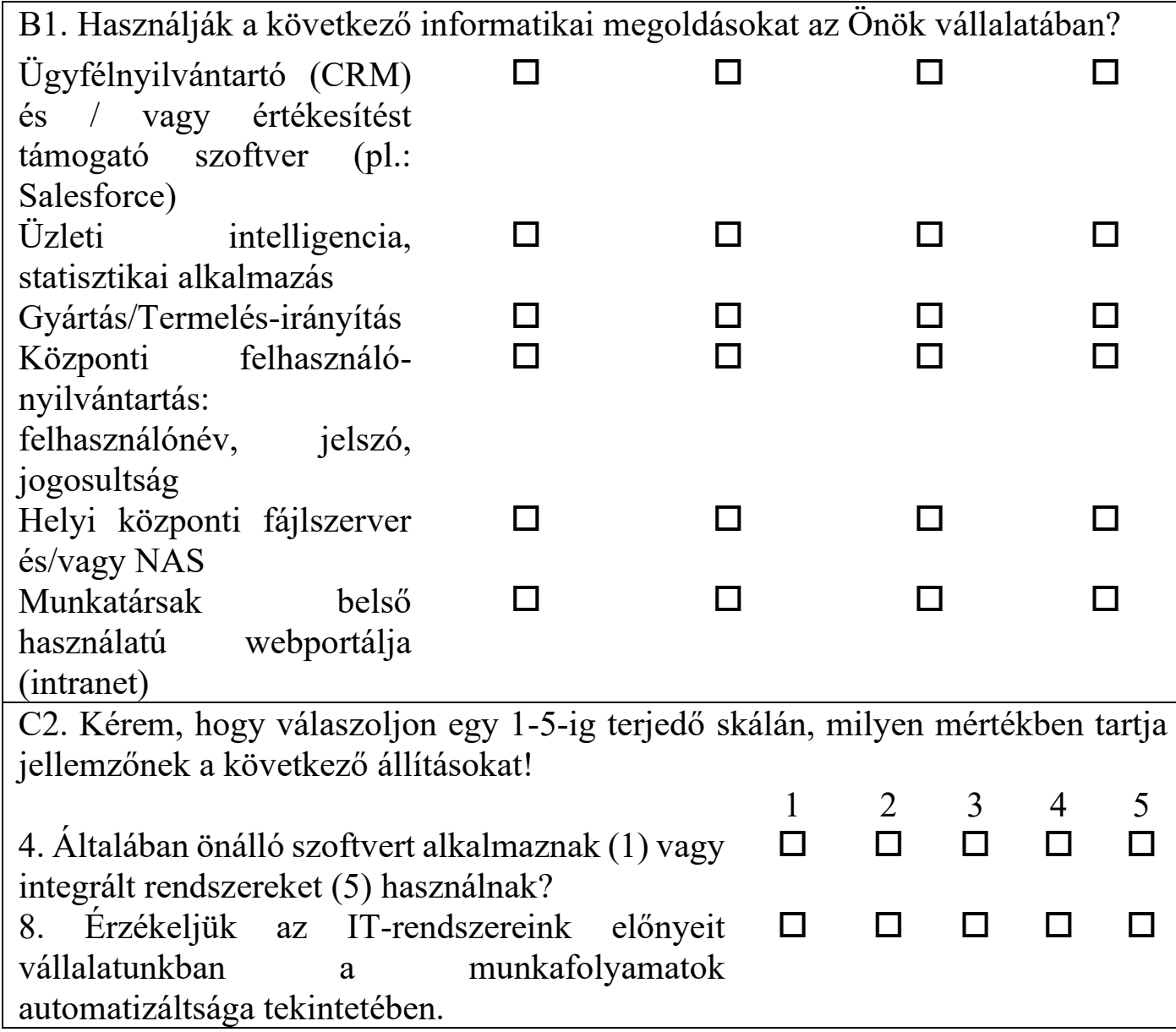

Forrás: A szerző saját szerkesztése

A B1-jelű kérdések megfogalmazásánál cél volt, hogy egyrészröl a porteri értéklánc-modell mindegyik tevekénységéhez hozzárendelhető legyen legalább egy szoftver-komponens. Szempont volt továbbá a kérdések megfogalmazásánál, hogy a kérdések akkor is megválaszolhatóak legyen, ha a válaszadó föképp integrált vállalatirányítási rendszert alkalmaz, és akkor is, ha az általa üzemeltetett szoftverkörnyezet fóképp szigetszerủ megoldásokból épül fel. Sajnos a korábbi publikációk áttekintése során nem találtam olyan szoftver-környezet feltérképezésére vonatkozó kérdéseket, amelyet mintegy „,best practice” akár részlegesen integrálni tudtam volna a kutatásomba. Az általam alkalmazott kérdésfeltevés módja még a közelmúltban publikált kutatásokhoz képest is előrelépést jelent (a teljesség igénye nélkül: Awa et al., 2017; Al-Shboul, 2019; Lufti, 2020), mert a hivatkozott publikációkban (is) csak annyit vizsgálnak, hogy a válaszadók körében valamilyen vállalatirányítási rendszer bevezetésre került-e / bevezetés alatt áll-e, vagy sem. Azt azonban nem vizsgálták, hogy vállalatirányítási rendszer bevezetése esetén a válaszadók mely modulokat használják, pedig egyes kutatások rámutattak, hogy meglehetösen ritka az olyan gazdálkodó szervezet, amely teljeskörüen vezetne be egy vállalatirányítási rendszert (Khadrouf et al., 2020). További előrelépést jelent, hogy a nemleges válasz esetében 
rákérdeztem arra, hogy milyen okból kifolyólag nem alkalmaznak bizonyos szoftvereket. Azaz azért nem kerülnek bizonyos típusú szoftverek vagy modulok alkalmazásra, mert a válaszadó müködése szempontjából nem releváns, vagy az adott tevékenységet kiszervezték, vagy nem tartják fontosnak, hogy az adott vállalati tevékenységet informatikai megoldásokkal támogassák.

A B1-jelü kérdéseket kiegészíti a C2/4 kérdés is, amely kérdésben visszatükröződik a korábbi kutatásokból levont, és az előzőekben megfogalmazott tapasztalat, miszerint a vállalati szoftverkörnyezet vizsgálatában nem elegendö csupán egy integrált rendszer meglétét feltételezni. A B1-jelü kérdésben feltett egyes alkalmazás-típusokra adott válaszokat a következö, 2. ábrán mutatom be:

\section{2. ábra: A szoftverkörnyezetre vonatkozó kérdésekre kapott válaszok összefoglalása}

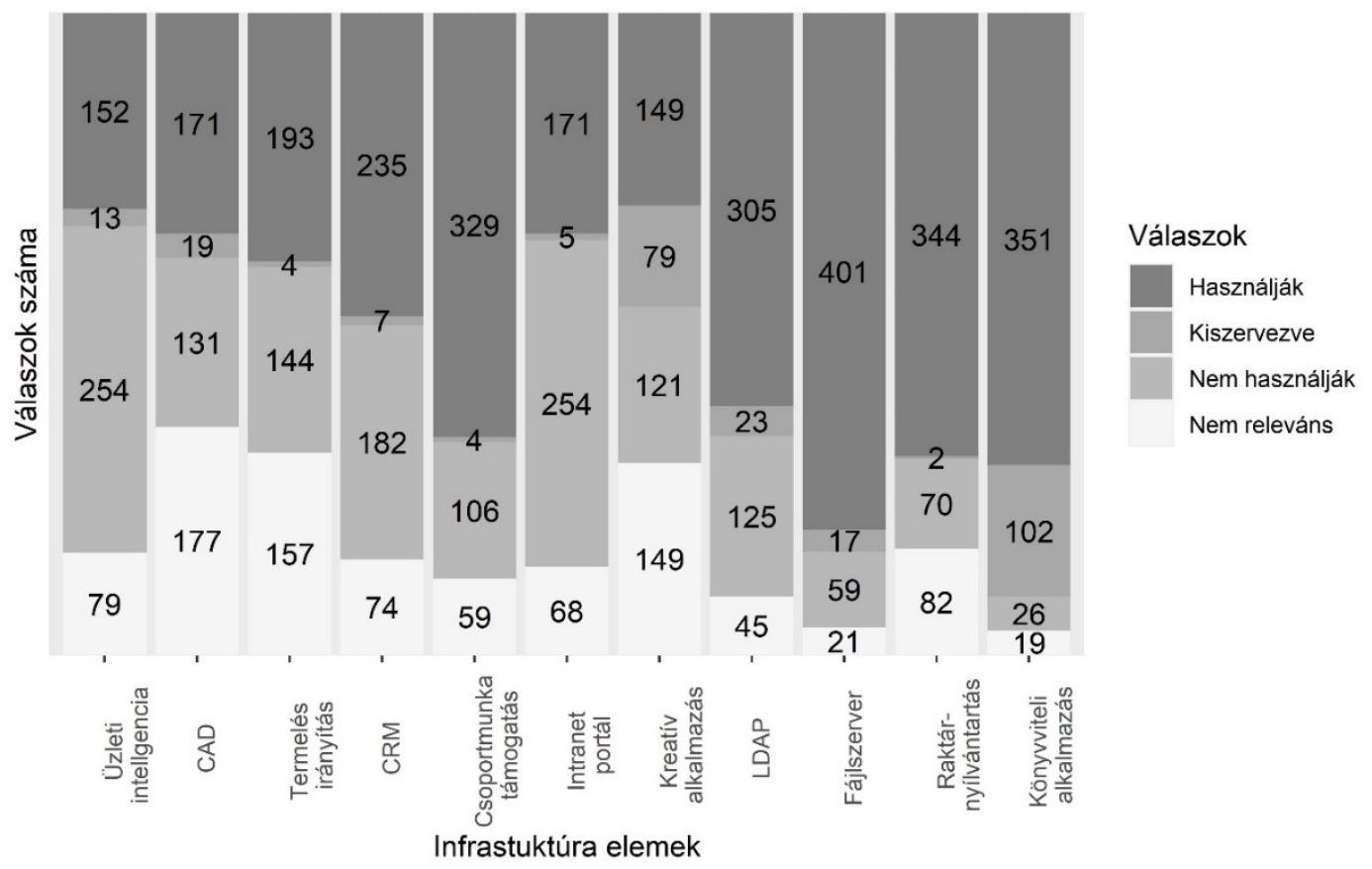

Forrás: A szerző saját szerkesztése

A C2/4 jelü kérdés esetében egy ötfokozatú Likert-skálán kellett arra választ adni, hogy az üzleti folyamatok támogatására elsősorban sziget-szerü megoldásokat vagy integrált megoldásokat alkalmaznak. (1-es érték jelentette, hogy nem vagy alig alkalmaznak integrált rendszereket, 5-ös, hogy gyakorlatilag minden üzleti folyamatot integrált rendszer támogat.) A válaszadók 15,26\%-a adott 1-es értéket (76 válasz), 11,04\%-a 2 -es értéket (55 válasz), 26,71\%-a 3-as értéket (133 válasz), 26,31\%-a adott 4-es értéket (131 válasz) és 20,68\%-a 5-ös értéket válaszként. Ez azt is jelenti, hogy a válaszadók kevesebb mint a fele $(46,99 \%)$ esetében vélelmezhető többé-kevésbé homogén alkalmazás-portfólió. Ez viszont nem indokolható pusztán erőforrás-hiánnyal, hiszen, ha megvizsgáljuk az 1. táblázatban közölt adatokkal a válaszadók 71,71\%-a olyan gazdálkodó szervezet volt, amelynek a mérlegföösszege 
nem haladta meg a 10 millió forintot és 50 fönél kevesebb munkatársat alkalmaztak. Megvizsgáltam, hogy a különböző infrastrukturális elemek alkalmazásai között milyen mértékü korreláció mutatható ki. (Korrelogram terjedelmi okokból nem kerül bemutatásra.) Ennek során 1-es értéket kapott az az eset, ha egy válaszadó használja az adott szoftver-elemet, 0-ás értéket, ha bármilyen okból nem használja. Az 55 lehetséges szoftver-párnál a legalacsonyabb korrelációs érték 0,02 , legmagasabb 0,38 volt, szignifikancia-vizsgálatok 34 esetben mutattattak $p<0,001$ valószínüség mellett, 12 esetben mutattak $\mathrm{p}<0,01$ valószínüségi szint mellett szignifikáns korrelációt. 5 esetben csak $\mathrm{p}<0,1$ valószínüségi szint mellett volt elfogadható a korreláció szignifikanciája, 4 esetben egyáltalán nem volt szignifikánsnak tekinthetö a számított korreláció. Ez azért is figyelemreméltó jelenség, mert ahogy az 1. ábrán is láthatjuk, hogy a legrosszabb esetben, a CAD-alkalmazások tekintetében is a válaszadók mindössze 35\%-a adta azt a választ, hogy a szoftver-infrastruktúra egy adott eleme nem releváns a vállalkozás számára, az összes többi esetben ez az érték alacsonyabb volt. Regressziós modellt állítottam fel annak megerösítésére, hogy egy vállalatirányítási-rendszer bevezetése növeli a vállalaton belüli informatikailag támogatott tevékenységek számát. A modellépítés a következő eredményt adta:

$$
Y=\underset{(0,3151) \quad(0,0896)}{4,5718+0,6011 * X_{1}}
$$

ahol:

$Y=$ Szoftverelemek száma, amelyre „használják” választ adtak.

$X_{1}=$ A válaszadók által a C2/4 kérdésre adott válasz.

A modell ugyan mind a globális tesztelésre $(\mathrm{F}=45,04, \mathrm{df}=1$ és 496, $\mathrm{p}=1,021 \mathrm{e}-11$ ), mind a változók parciális tesztelésére (mind a konstans, mind az $X_{1}$ változó esetében $\mathrm{p}<0,001)$ szignifikáns lett, bár a magyarázó értékét alacsonynak kell tekinteni $\left(R^{2}=0,0833\right.$ és korrigált $\left.R^{2}=0,0814\right)$. Az alacsony magyarázó erő ellenére meglátásom szerint kimutatható az a (részleges) hatás, hogy gyakran egy integrált vállalatirányítási rendszer bevezetése eredményezi az üzleti folyamatok nagyobb arányú informatikai támogatottságát.

A kérdőíves válaszok elemzésében felmerült, hogy a $\mathrm{B} 1$ jelü kérdés alkérdéseire beérkezett válaszok az adatbányászati eljárásokból ismert mintázat-elemzési eljárás segítségével kerüljenek elemzésre. Ez több ok miatt nem bizonyult járható útnak. Egyrészt a nemzetközi publikációkat áttekintve egy-egy sikeres mintázat-keresési eljárás sokkal nagyobb válaszadói sokaságra épült: Lei et al. (2019) 1893 rekord nagyságú adatbázison ért el jelentős eredményeket és Crozier et al. (2009) kutatásában az alapminta meghaladta a 12500 föt. Másrészt a 498 beérkezett válasz 441 különféle mintázatot követett, ebből egy mintázat gyakorisága 13, egy mintázatnak volt 5 , szintén egy mintázatnak volt 4 válaszadói gyakorisága, 6 mintázatnak volt 3, 26 mintázatnak volt 2 válaszadói gyakorisága, és az összes többi mintázat 1-1 válaszadó kitöltéséből épült fel. Követve Yilmaz el al. (2016) 577 beérkezett válaszon és Tsironis et al. (2016) 174 beérkezett kérdőíves válaszon alapuló eljárását, feltáró faktorelemzés (EFA) eredményeire építve konfirmatív faktorelemzés (CFA) segítségével látens-változókat építettem fel (Moreira et al., 
2018). A CFA eljárás eredményeképpen létrejövő látens-változókból épült el az a mutatószám-rendszer, amely képes lett reprezentálni a válaszadók által üzemeltetett szoftver-környezetet. Ezen eljárás sikerességi kritériumait a következőkben határoztam meg:

- A CFA-elemzés alapján felépülö modellből származó indikátor értékek a hasonló jellegü tudományos kutatásoknál alkalmazott elfogadási tartományba esnek.

- A CFA-elemzés alapján létrejött látens-változók szignifikáns korrelációt mutatnak a kérdőív más válaszaival. Jelen kutatásban ez a feltétel akkor teljesül, ha egy véletlenszerüen kiválasztott kérdésre ( $\mathrm{C} 2 / 8$ jelü kérdés) kapott válaszokkal - mint kontroll-változóval - legalább az egyik látens változó t-próbával igazolt szignifikáns korrelációt mutat.

- A látens-változók képesek betölteni regressziós modellek magyarázó változóit, azaz a látens-változók és a véletlenszerüen kiválasztott kérdésre kapott válaszokkal - mint kontroll-változókkal - felépített regressziós modellek legalább egyike esetében a globális tesztelés megerősíti a modell szignifikáns voltát.

- A látens-változók képesek betölteni regressziós modellek magyarázó változóit, azaz a látens-változók és a véletlenszerúen kiválasztott kérdésre kapott válaszokkal - mint kontroll-változókkal - felépített regressziós modellek legalább egyike esetében felépített modell változóinak parciális tesztelései megerösítik a modell szignifikáns voltát.

A klaszter-elemzések során a korreláció-számítástól eltérő módon értékeltem az B1 kérdésekre kapott válaszokat:

- Továbbra is 1-es értéket kapott, ha az adott válaszadó alkalmazta az adott típusú szoftvert.

- $\quad 0$-s értéket kapott abban az esetben, ha az adott szoftverelem nem volt releváns a válaszadó számára, mert ez esetben nem érte a válaszadót hátrány, ha nem használta az adott típusú szoftvert. Szintén 0 értéket kapott, ha az adott szoftverrel támogatható tevékenység kiszervezésre került, mert ezzel feltételezhetjük, hogy a gazdálkodó szervezet nem informatikai okokra visszavezethető hatékonyság-növekedést ért el (Hauck, 2014). A kiszervezéssel az adatfeldolgozás is kikerült a vállalat köréből, így az adott tevékenység informatikai támogatásából nem származhat az az előny, hogy az ott képződött adatokat bármilyen más célra is felhasználják.

- -1-es értéket kapott, ha a válaszadó a „,nem használunk” választ adta, egyrészről mert feltételezzük, hogy így az adott üzletviteli tevékenységet informatikai támogatással hatékonyabban is el lehetne látni, és az információs támogatás hiányában nem képződik olyan adatvagyon, amelyet más területen fel lehetne használni, így lemondanak bizonyos szinergiahatásról. Ez egy újszerü megközelítés, hiszen még a közelmúlt vállalatirányítási-rendszereket érintő kutatások kérdésfeltevései is csak arra korlátozódtak, hogy implementálásra került-e egy integrált rendszer, vagy sem. Nem vizsgálták azonban, hogy milyen hatások azonosíthatóak akkor, 
amikor létjogosultsága lenne egy adott tevékenység informatikai támogatására, viszont erre mégsem kerül sor.

Első lépésként az összes, a kérdőívben feltett 11 változó bevonásával elöállítottam egy két klasztert feltételező elemzést, amelynek a diagonális értékekre mért illeszkedése 0,96-os értéket ért el. Erre alapozva később felállítottam két CFAmodellt. A két faktort tartalmazó modell eredményét a következö, 3 táblázatban mutatom be.

3. táblázat: Eredeti adatfelvételen alapuló klaszter-elemzés

\begin{tabular}{|l|r|r|r|r|r|}
\hline Változó neve & MR1 & MR2 & h2 & u2 & com \\
\hline h_groupw & $\mathbf{0 , 5 2}$ & 0,01 & 0,28 & 0,72 & 1,0 \\
\hline h_raktar & 0,03 & $\mathbf{0 , 5 7}$ & 0,34 & 0,66 & 1,0 \\
\hline h_konyvv & 0,20 & 0,26 & 0,16 & 0,84 & 1,9 \\
\hline h_cad & $\mathbf{0 , 1 3}$ & $\mathbf{0 , 3 2}$ & 0,17 & 0,83 & 1,3 \\
\hline h_bi & $\mathbf{0 , 4 3}$ & 0,16 & 0,29 & 0,71 & 1,3 \\
\hline h_termir & $-0,03$ & $\mathbf{0 , 6 7}$ & 0,44 & 0,56 & 1,0 \\
\hline h_ldap & $\mathbf{0 , 4 5}$ & 0,10 & 0,26 & 0,74 & 1,1 \\
\hline h_intran & $\mathbf{0 , 6 5}$ & $-0,11$ & 0,36 & 0,64 & 1,1 \\
\hline h_nas & 0,29 & 0,26 & 0,23 & 0,77 & 2,0 \\
\hline h_creativ & $\mathbf{0 , 3 3}$ & 0,10 & 0,16 & 0,84 & 1,2 \\
\hline h_crm & $\mathbf{0 , 3 6}$ & 0,13 & 0,20 & 0,80 & 1,2 \\
\hline
\end{tabular}

Forrás: A szerző saját szerkesztése

Az EFA-elemzés eredményei alapján a további elemzésből kizártam kettő, a komponens mátrixban alacsony, 0,30-as értéket el nem érő változót. Erre az eredményre alapozva két CFA-modellt állítottam fel: az 1. modell módosítás nélkül a 3. táblázatban bemutatott EFA-elemzésre alapul, azaz két látens változót feltételez:

- LV1_a: h_groupw, h_bi, h_ldap, h_intran, h_crm, h_creativ

- LV2_a: h_raktar, h_cad, h_termir

Az 1. modell LV2_a látens változója egyértelműen megfeleltethető a porteri értéklánc-modell elsődleges tevékenységének, és az LV1_a látens változó megfeleltethető a támogató-tevékenységeknek. Ennek kapcsán meg kell említeni, hogy fundamentalista értelmezés szerint az ügyfélkapcsolat-kezelö rendszereknek (CRM) az LV2_a látens változóhoz kellene tartoznia, de a CRM-rendszerek ugyanúgy felhasználhatnak pénzügyi adatokat (pl.: bevétel alakulása) mint természetbeni adatokat (pl.: fogyasztói szokások) is (Rygielski et al., 2002). Hasonló a helyzet az üzleti intelligencia (BI) megoldások esetében is, hogy müködésükben pénzügyi és nem pénzügyi jellegü adatokra is támaszkodik. Ebböl a különleges helyzetből adódhat a CRM-rendszerek BI-rendszerekkel mutatott, a többi komponens-párok között mért korrelációhoz viszonyított relatív magas korrelációs mértéke $(\mathrm{r}=0,35 ; \mathrm{t}=8,2905 ; \mathrm{p}=1,066 \mathrm{e}-15)$. Ennek a következménye, hogy ugyanannak a látens-változónak alkotóelmeivé váltak. A módosított modellben az LV1_a látens változót bontom további két részre, ennek alapján a 2. modell a következőképp épül fel: 
- LV1_b: h_groupw, h_ldap, h_intran, h_creativ;

- LV2_b: h_raktar, h_cad, h_termir;

- LV3_b: h_bi; h_crm;

Az elöbb bemutatott két modell indikátorai a következöképp alakultak (4. táblázat):

4. táblázat: A CFA-modellek indikátorai, valamint annak kritikus értéke

\begin{tabular}{|c|c|c|c|}
\hline $\begin{array}{l}\text { Indikátor } \\
\text { megnevezése }\end{array}$ & Elvárt érték & 1. modell & 2. modell \\
\hline$\chi^{2}$ & $\begin{array}{l}\text { Awang (2015): A } \chi 2 \text { szabadságfok } \\
\text { hányados értelmezett } \\
\text { Schreiber et al (2014): A } \chi 2 \text { szabadságfok } \\
\text { hányados értelmezett }\end{array}$ & 44,913 & 33,709 \\
\hline $\begin{array}{l}\text { ¿2-hez } \\
\text { tartozó p- } \\
\text { érték }\end{array}$ & $\begin{array}{l}\text { Awang (2015): } \mathrm{p}>0,05 \text {, ha } \mathrm{n}<200 \\
\text { Koltai (2013): } \mathrm{p}>0,01 \\
\text { Boonda (2019): } \mathrm{p}>0,05\end{array}$ & 0,012 & 0,09 \\
\hline $\begin{array}{l}\text { Comparative } \\
\text { Fit Index } \\
\text { (CFI) }\end{array}$ & $\begin{array}{l}\text { Awang (2015): CFI }>0,90 \\
\text { Koltai (2013): CFI }>0,90 \\
\text { Boonda (2019): CFI }>0,90 \\
\text { Pajkossy et al (2015): CFI }>0,96 \\
\text { Schreiber et al (2014): CFI }>0,95\end{array}$ & 0,965 & 0,982 \\
\hline $\begin{array}{l}\text { Tucker- } \\
\text { Lewis Index } \\
\text { (TLI) }\end{array}$ & $\begin{array}{l}\text { Awang (2015): TLI }>0,90 \\
\text { Schreiber et al (2014): TLI >0,95 }\end{array}$ & 0,952 & 0,973 \\
\hline $\begin{array}{l}\text { Akaike } \\
\text { (AIC) }\end{array}$ & $\begin{array}{l}\text { Pajkossy et al (2015): Nincs kritikus érték, } \\
\text { alacsonyabb érték jobb teljesítményt } \\
\text { mutat. } \\
\text { Schreiber et al (2014): nincs kritikus } \\
\text { érték. }\end{array}$ & 10466,28 & 10459,07 \\
\hline $\begin{array}{l}\text { Bayesian } \\
\text { (BIC) }\end{array}$ & $\begin{array}{l}\text { Pajkossy et al (2015): Nincs kritikus érték, } \\
\text { alacsonyabb érték jobb teljesítményt } \\
\text { mutat. } \\
\text { Schreiber et al (2014): nincs kritikus } \\
\text { érték. }\end{array}$ & 10546,28 & 10547,48 \\
\hline RMSEA & $\begin{array}{l}\text { Awang (2015): RMSEA }<0,08 \\
\text { Koltai (2013): RMSEA }<0,05 \\
\text { Boonda (2019): RMSEA }<0,05\end{array}$ & 0,038 & 0,029 \\
\hline SRMR & Schreiber et al (2014): SRMR $<0,08$ & 0,036 & 0,032 \\
\hline
\end{tabular}

Forrás: A szerző saját szerkesztése

A 4. táblázatban nem került külön feltüntetésre, de minkét modell teljesíti a Schreiber et al. (2014) publikációjában ismertetett feltételt, azaz a $\chi 2 /$ szabadságfok hányados nem éri el a 2,00-ás értéket. Amint a 4. táblázatból is láthatunk, mindkét modell indikátorai az elfogadási tartományon belüli értéket vettek fel. A 2. modell bár nem teljesen az EFA-elemzés eredményei épül, szemléletében jobban illeszkedik 
a kutatás elméleti alapjainál bemutatott elméleti modellekhez amellett, hogy indikátorai az AIC és BIC értékek kivételével jobb értéket értek el. Mansoureh et al. (2016) kutatásában úgy fogadták el szignifikánsnak a felállított modellt, hogy egyedül a $\chi 2$-hez tartozó p-érték nem érte el a kívánt szintet, viszont a többi indikátor a modellje szempontjából kritikus tartományba estek. A modell használhatóságát mutatja az a tény is, hogy a látens-változók mindegyik alkotóeleme szignifikáns, ahogyan azt a következö, 5. táblázatban bemutatom:

5. táblázat: A látens-változók struktúrája és indikátorai

\begin{tabular}{|l|l|l|l|l|l|}
\hline $\begin{array}{l}\text { Látens } \\
\text { változó neve }\end{array}$ & Változó neve & $\begin{array}{c}\text { Becsült } \\
\text { együttható }\end{array}$ & $\begin{array}{c}\text { Standard } \\
\text { hiba }\end{array}$ & z-érték & $\mathrm{P}(>|\mathrm{z}|)$ \\
\hline \multirow{4}{*}{ LV1 } & h_groupw & 1,000 & & & \\
\cline { 2 - 6 } & h_ldap & 0,922 & 0,128 & 7,217 & 0,000 \\
\cline { 2 - 6 } & h_intran & 1,110 & 0,144 & 7,728 & 0,000 \\
\cline { 2 - 6 } & h_creativ & 0,652 & 0,103 & 6,348 & 0,000 \\
\hline \multirow{4}{*}{ LV2 } & h_raktar & 1,000 & & & \\
\cline { 2 - 6 } & h_cad & 0,917 & 0,138 & 6,655 & 0,000 \\
\cline { 2 - 6 } & h_termir & 1,409 & 0,190 & 7,429 & 0,000 \\
\hline \multirow{2}{*}{ LV3 } & h_bi & 1,000 & & & \\
\cline { 2 - 6 } & h_crm & 0,833 & 0,111 & 7,582 & 0,000 \\
\hline
\end{tabular}

Forrás: A szerző saját szerkesztése

Ez alapján a következő látens változókát lehet felépíteni:

$$
\begin{aligned}
L V 1 \_b= & 1,000 * h \_g r o u p w+0,922 * h \_l d a p+1,110 * h \_ \text {intran }+ \\
& +0,652 * h \_c r e a t i v \\
L V 2 \_b= & 1,000 * h \_r a k t a r+0,917 * h \_c a d+1,409 * h \_t e r m i r \\
L V 3 \_b= & 1,000 * h \_b i+0,833 * h \_c r m
\end{aligned}
$$

A három látens változó a következőképp értelmezhető:

- Az LV1_b látens változó reprezentálja a támogató tevékenységekben közremúködő szoftveres megoldásokat;

- Az LV2 b látens változó reprezentálja az elsődleges tevékenységekben közremüködő szoftveres megoldásokat;

- Az LV3_b látens változó olyan alkalmazásokat reprezentál, amely köthetőek mind az elsődleges, mind a támogató tevekénységekhez. Ahogy Michelberger (2001) és Chou et al (2005) cikkében láthatjuk, az üzleti intelligencia rendszerek által felhasznált adatok származhatnak elsődleges tevékenységet- és támogató tevékenységhez kapcsolódó szoftverekből vagy modulokból.

A szemantikai verifikálás végett megvizsgáltam, hogy az LV1_b, LV2_b és LV3_b egy kontroll-kérdés viszonylatában be tudja-e tölteni a magyarázó-változó szerepét. A kérdőív C2/8-as kérdését választottam ki kontroll szerepre, mert egy TAM-modellben képes „észlelt hasznosság” kategóriát reprezentálni. Ehhez hasonlóan a TOE-modellben, ahol a látens változók a Technológia kategóriához 
tartoznak, a kontroll kérdés a modell eredmény-változójának szerepét tudja betölteni. A korrelációs-kapcsolatok méréseinek eredményeit a 6. táblázatban foglalom össze.

\section{6. táblázat: A látens változók és kontroll-változó korrelációs kapcsolata}

\begin{tabular}{|l|c|c|c|c|c|c|}
\hline $\begin{array}{l}\text { változó } \\
\text { neve }\end{array}$ & $\begin{array}{c}\text { becsült } \\
\text { korreláció }\end{array}$ & $\begin{array}{c}\text { intervallum } \\
\text { felső határa }\end{array}$ & $\begin{array}{c}\text { intervallum } \\
\text { alsó határa }\end{array}$ & $\begin{array}{c}\text { t-próba } \\
\text { értéke }\end{array}$ & $\mathrm{df}$ & p-értéke \\
\hline LV1_b & 0,3618 & 0,4359 & 0,2830 & 8,6449 & 496 & $2,2 \mathrm{e}-16$ \\
\hline LV2_b & 0,2777 & 0,3568 & 0,1946 & 6,4373 & 496 & $2,873 \mathrm{e}-10$ \\
\hline LV3_b & 0,2645 & 0,3444 & 0,1809 & 6,1093 & 496 & $2,025 \mathrm{e}-09$ \\
\hline
\end{tabular}

Forrás: A szerző saját szerkesztése

Ezek alapján láthatóak, hogy a korrelációs kapcsolatok bár mindegyik esetben szignifikánsak, de ezek kapcsolatok gyenge-közepes mértéküek. Erre ez eredményre építve megvizsgálom, hogy a szignifikáns korrelációt mutató változók be tudják-e tölteni regressziós modellek magyarázói változóinak szerepét. Az eredményeket a 7., 8. és 9. táblázatban foglalom össze:

\section{7. táblázat: Az LV1_b látensváltozó és kontroll-változó közötti regressziós modell ANOVA-táblája}

\begin{tabular}{|c|c|c|c|c|c|c|}
\hline \multicolumn{2}{|l|}{ R2: } & \multicolumn{5}{|l|}{0,1309} \\
\hline \multicolumn{2}{|l|}{ Korrigált R2: } & \multicolumn{5}{|l|}{0,1292} \\
\hline \multicolumn{2}{|l|}{ F-próba } & \multicolumn{5}{|l|}{74,73} \\
\hline \multicolumn{2}{|l|}{ Szabadságfok: } & \multicolumn{5}{|l|}{1 és 496} \\
\hline \multicolumn{2}{|l|}{ p-érték: } & \multicolumn{5}{|l|}{$<2,2 \mathrm{e}-16$} \\
\hline \multicolumn{2}{|l|}{ Változó neve } & Becsült érték & St. hiba & t-érték & $\operatorname{Pr}(>|t|)$ & szig. \\
\hline Tengelymetszet & $(\beta 0)$ & 3,3165 & 0,0548 & 60,462 & $<2 \mathrm{e}-16$ & $* * *$ \\
\hline LV1_b & $(\beta 1)$ & 0,2171 & 0,0251 & 8,645 & $<2 \mathrm{e}-16$ & $* * *$ \\
\hline \multicolumn{2}{|c|}{ Szignifikancia kódok: } & $* * *: 0,001$ & $* *: 0,01$ & $*: 0,05$ & ".":0,1 & $" \%: 1$ \\
\hline
\end{tabular}

Forrás: A szerző saját szerkesztése

8. táblázat: Az LV2_b látensváltozó és kontroll-változó közötti regressziós modell ANOVA-táblája

\begin{tabular}{|c|c|c|c|c|c|c|}
\hline \multicolumn{2}{|l|}{ R2: } & \multicolumn{5}{|l|}{0,0771} \\
\hline \multicolumn{2}{|l|}{ Korrigált R2: } & \multicolumn{5}{|l|}{0,0752} \\
\hline \multicolumn{2}{|l|}{ F-próba } & \multicolumn{5}{|l|}{41,44} \\
\hline \multicolumn{2}{|l|}{ Szabadságfok: } & \multicolumn{5}{|l|}{1 és 496} \\
\hline \multicolumn{2}{|l|}{ p-érték: } & \multicolumn{5}{|l|}{$2,873 \mathrm{e}-10$} \\
\hline \multicolumn{2}{|l|}{ Változó neve } & Becsült érték & St. hiba & t-érték & $\operatorname{Pr}(>|t|)$ & szig. \\
\hline Tengelymetszet & $(\beta 0)$ & 3,3159 & 0,0582 & 56,986 & $<2 \mathrm{e}-16$ & $* * *$ \\
\hline $\mathrm{LV} 2 \_b$ & $(\beta 1)$ & 0,1808 & 0,0281 & 6,437 & $2,87 \mathrm{e}-10$ & $* * *$ \\
\hline \multicolumn{2}{|c|}{ Szignifikancia kódok: } & $* * *: 0,001$ & $* *: 0,01$ & $*: 0,05$ & ".:0,1 & $": 1$ \\
\hline
\end{tabular}


9. táblázat: Az LV3_b látensváltozó és kontroll-változó közötti regressziós modell ANOVA-táblája

\begin{tabular}{|c|c|c|c|c|c|c|}
\hline \multicolumn{2}{|l|}{ R2: } & \multicolumn{5}{|l|}{0,0700} \\
\hline \multicolumn{2}{|l|}{ Korrigált R2: } & \multicolumn{5}{|l|}{0,0681} \\
\hline \multicolumn{2}{|l|}{ F-próba } & \multicolumn{5}{|l|}{37,32} \\
\hline \multicolumn{2}{|l|}{ Szabadságfok: } & \multicolumn{5}{|l|}{1 és 496} \\
\hline \multicolumn{2}{|l|}{ p-érték: } & \multicolumn{5}{|l|}{$2,025 \mathrm{e}-09$} \\
\hline \multicolumn{2}{|l|}{ Változó neve } & Becsült érték & St. hiba & t-érték & $\operatorname{Pr}(>|t|)$ & szig. \\
\hline Tengelymetszet & $(\beta 0)$ & 3,4824 & 0,0545 & 63,882 & $<2 \mathrm{e}-16$ & $* * *$ \\
\hline LV3 $b$ & $(\beta 1)$ & 0,2466 & 0,0404 & 6,109 & $2,03 e-09$ & $* * *$ \\
\hline \multicolumn{2}{|c|}{ Szignifikancia kódok: } & $* * *: 0,001$ & $* *: 0,01$ & $*: 0,05$ & ".": 0,1 & $" ”: 1$ \\
\hline
\end{tabular}

Forrás: A szerző saját szerkesztése

Ahogy a három ANOVA-táblán látható, az egyes regressziós modellek a globális tesztelés és az egyes változók parciális tesztelése alapján is szignifikánsnak bizonyultak.

Miután a látens-változók alapjául szolgáló szignifikáns CFA-modellt csak bizonyos változók elhagyásával lehetett felépíteni, így körültekintően kell eljárni a modell értelmezése és további alkalmazása során. A könyvviteli alkalmazások alacsony korrelációja két dologgal magyarázható: egyik oka, hogy a könyvviteli / számviteli alkalmazások feladatát sokszor kiszervezik. Másik lehetséges ok, hogy ha egy integrált vállalat-irányítási rendszer egyik modulja támogatja a számviteli tevékenységeket, akkor a válaszadók esetleg nem feltétlenül tudják különválasztani az BI-rendszerek müködésétől (Tamandeh, 2016; Rikhardsson-Yigitbasioglu, 2018). Nem igazolható ugyan statisztikailag, de feltételezem, hogy e kettő változó aszimmetrikus mértékben ugyan, de kölcsönösen gyengítették egymást.

\section{Eredmények értékelése, korlátozások és továbbfejlesztési lehetőségek}

Sikerült a cikk elején megfogalmazott célkitüzéseket elérni, azaz felépítésre került, egy statisztikai eljárásokkal alátámasztatott, a vállalati szoftverkörnyezetet reprezentálni képes mutatószám-rendszer, illetve modellt. A most bemutatott és felállított modell indikátorai által igazolt módszertani eljárás elörelépést jelent a kérdésfeltevés módjában, a kapott adatok feldolgozásában, és az elemzés tekintetében is: a kvantitatív szempontok mellett érvényesülhettek a kvalitatív szempontok is, azaz a modell megfeleltethető azokkal a 2 . fejezetben bemutatott elméleti modellekkel (például: értéklánc-modell). A részkutatás továbbá választ adott a 2. fejezetben feltett kérdésekre: megerősítette a korábbi kutatások által felvetett problémát, miszerint a magyarországi gazdálkodó szervezetek esetében még mindig ellentmondásos az üzleti tevékenységek informatikai támogatottságával, és nem feltétlenül mérik fel az integrált vállalati adatvagyonból fakadó szinergikus előnyöket. Emellett egyes üzleti területen a kiszervezések is jelentős akadályt képeznek arra, hogy a gazdálkodó szervezetek életben keletkező adatok és információk lehetőleg egy informatikai rendszerben koncentrálódjon. 
Az ebben a cikkben bemutatott eljárást és annak eredményeképp felállított modellt több módon lehet közvetlenül felhasználni. Egyik ilyen lehetőség, hogy a látens változókat magyarázó változóként felhasználva számszakilag is meg lehet vizsgálni, hogy kimutathatóak-e azok a vállalati növekedésben és hatékonyságjavulásban realizálódó előnyök, amelyet több elméleti és kvalitatív kutatás (Teittinen et al., 2012; Tarutè-Gatautis., 2013) is igazolni próbált.

A modell másik leendő felhasználási területe, hogy a látens-változók, valamint információbiztonság területén a megelőző tevékenységekre és incidensekre vonatkozó változók (mindkettőre vonatkozott kérdés a kérdőívben) bevonásával további statisztikai modelleket lehet megalkotni. E módon mérhetővé válhat, hogy a gazdálkodó szervezetek IKT-infrastruktúrája milyen hatást gyakorol az üzemeltető szerveztek kockázati térképére és információbiztonsági érettségére.

Nagyon nehéz kérdés, hogy egy esetleges jövőbeli kutatás során hogyan érdemes feltenni a szoftverkörnyezetre vonatkozó kérdéseket, hogy az azokra kapott válaszokra támaszkodó modellek jobb illeszkedést mutassanak és nagyobb magyarázó erőt tudjanak képviselni. Az irodalom-feldolgozás és a kérdőívre beérkezett válaszok statisztikai elemzése során leszürt tapasztaltok alapján a B1 jelü kérdéshez hasonló kérdés feltételekor még szofisztikáltabb válasz-lehetőségeket lenne érdemes adni:

- Nem használunk ilyen megoldásokat, mert nem releváns;

- Nem használunk ilyen megoldásokat, mert kiszerveztük az ezzel kapcsolatos feladatokat;

- Nem használunk ilyen megoldásokat;

- Használunk ilyen megoldásokat, kifejezetten erre a célra fejlesztett szoftverrel;

- Használunk ilyen megoldásokat, kifejezetten erre a célra fejlesztett szoftverrel és egy integrált vállalatirányítási-rendszer egy vagy több moduljával együttesen;

- Használunk ilyen megoldásokat, csak integrált vállalatirányítási-rendszer egy vagy több moduljának támogatásával.

Az előzőek analógiájára az egyes tevékenységi köröket is érdemes lenne megkülönböztetni az alapanyag-, félkészárú- és készárú raktározási tevékenységet, a könyviteli feladatok mellé érdemes külön bérszámfejtési feladatokra is rákérdezni. A CRM-rendszereket esetében érdemes lenne különválasztani az ügyfélszolgálati-, és marketing tevékenységeket, illetve rákérdezni az ajánló rendszerek meglétére.

\section{Köszönetnyilvánítás}

Ezúton szeretném a Budapesti Kereskedelmi és Iparkamara erkölcsi támogatását és kutatás lebonyolításában való közremüködését. A jelen kutatás létrejöttét a 20171.3.1-VKE-2017-00031 azonosítószámú, „Nagy pontosságú burkolat vizsgáló mérési technológia alapjainak kutatási programja” pályázat támogatta. 


\section{Irodalomjegyzék}

Al-Shboul, M. A. (2019), Towards better understanding of determinants logistical factors in SMEs for cloud ERP adoption in developing economies. Business Process Management Journal 25 (5): 887-907. https://dx.doi.org/10.1108/BPMJ-01-2018-0004

Alves, M. d. C, Matos, Amaral S. I. (2013): ERP adoption by public and private organizations - a comparative analysis of successful implementations. Journal of Business Economics and Management 14 (3): 500-519. https://dx.doi.org/10.3846/16111699.2011.652979

Aversano, L., Grasso C., Tortorella M. (2012): A Literature Review of Business/IT Alignment Strategies. Procedia Technology, 5: 462-474. https://doi.org/10.1016/j.protcy.2012.09.051.

Awa, H. O., Ukoha O., Emecheta B. C. (2016): Using T-O-E theoretical framework to study the adoption of ERP solution. Cogent Business \& Management, 3 (1) corpus: 1196571. https://dx.doi.org/10.1080/23311975.2016.1196571

Awa, H. O., Uko J. P., Ukoha O. (2017): An Empirical Study of Some Critical Adoption Factors of ERP Software. International Journal of Human-Computer Interaction, 33 (8): 609-622. https://dx.doi.org/10.1080/10447318.2016.

Awang, Z. (2015), SEM MADE SIMPLE, MPWS RICH PUBLICATION SDN BHD, ISBN: 978967-0942-26-1

Boonda, P. (2019): Conducting a Path analysis of Virtual Service Provider Office Management (VSPOM) Structure for Service Plan in the Regional Health Service. Thailand Indian Journal of Forensic Medicine \& Toxicology, $13 \quad$ (4): 1799-1805. https://dx.doi.org/10.37506/ijfmt.v13i4.3359

Chang, H., Kim, J., Lim, S. (2006): Information Security Management System for SMB in Ubiquitous Computing In: Gavrilova M.L. et al. (eds): Computational Science and Its Applications - ICCSA 2006. ICCSA 2006 Lecture Notes in Computer Science, vol 3983., Springer, Berlin, Heidelberg. ISBN: 978-3-540-34077-5. 707-715. https://dx.doi.org/10.1007/11751632_77

Chou, D. C., Bindu Tripuramallu, H., Chou, A.Y (2005): BI and ERP integration. Information Management \& Computer Security, $13 \quad$ (5): 340-349. https://doi.org/10.1108/09685220510627241

Coldewey, J. (2007): Lohnt sich SOA? In: Starke G., Tilkov, S. (Hrsg.): SOA-Expertwissen Methoden Konzepte und Praxis serviceorientierter Arichtekturen. dpunkt.verlag, Heidelberg. ISBN: 978-3898644372., 49-57.

Crozier, S., Inskip, H., Barker, M., Lawrence, W. T., Cooper, C., Robinson S. M. (2010): Development of a 20-item food frequency questionnaire to assess a 'prudent' dietary pattern among young women in Southampton. European Journal of Clinical Nutrition, 64: 99-104. https://dx.doi.org/10.1038/ejcn.2009.114

Davis, F. D. (1989): Perceived Usefulness, Perceived Ease of Use, and User Acceptance of Information Technology. MIS Quraterly, 13 (3): 319-340. https://dx.doi.org/10.2307/249008

Drótos Gy., Móricz P. (2012): A vállalati informatika szerepe a versenyképesség alakításában a pénzügyi és gazdasági válság időszakában. Vezetéstudomány, 43 (2. Különszám): 80-89.

Hasselbring, W. (2000): Information system integration. COMMUNICATIONS OF THE ACM, 43 (6): 32-38. https://dx.doi.org/10.1145/336460.336472

Hauck Zs. (2014): Az outsourcing és az integráció közötti választás szempontjai, avagy minőség teszi a döntést. Vezetéstudomány, 45 (4): 41-50.

Hoque, Z., Mia, L., Alam, M. (2001): MARKET COMPETITION, COMPUTER-AIDED MANUFACTURING AND USE OF MULTIPLE PERFORMANCE MEASURES: AN EMPIRICAL STUDY. The British Accounting Review, 33 (1): 23-45. https://doi.org/10.1006/bare.2000.0149.

IEEE (N. A.): "What is the Enterprise IT BOK?" <http://eitbokwiki.org/Enterprise_Architecture> (2020. 08. 29.)

Khadrouf, O., Chouki, M., Talea, M., Bakali, A. (2020): Influence of SME characteristics on the implementation of ERP. Telkomnika, (18) 4: 1857-1865. http://dx.doi.org/10.12928/telkomnika.v18i4.13537 
Kordha, E., Gorica, K., Ahmeta, L. (2011): MANAGING IT INFRASTRUCTURE FOR INFORMATION SOCIETY DEVELOPMENT. THE ALBANIAN CASE. Romanian Economic and Business Review, 6 (2): 122-131.

Koltai J. (2013): A strukturális egyenletek modellezésének bemutatása egy komplex dizájnú kutatás (ISPJ) adatain keresztül. Szociológiai Szemle, (23) 2: 31-51.

Keszey T., Zsukk J. (2017): Az új technológiák fogyasztói elfogadása. A magyar és nemzetközi szakirodalom áttekintése és kritikai értékelése. Vezetéstudomány, 48 (10): 38-47. https://dx.doi.org/10.14267/VEZTUD.2017.10.05

Lei, H., Quweider, M., Zhang, L., Khan, F. (2019): Mining Survey Data in: 2nd International Conference on Data Intelligence and Security (ICDIS). IEEE, South Padre Island, TX, USA. ISBN:978-1-7281-2080-5, 201-207. http://dx.doi.org/10.1109/icdis.2019.00037

Lutfi, A. (2020): Investigating the Moderating Role of Environmental Uncertainty between Institutional Pressures and ERP Adoption in Jordanian SMEs. Journal of Open Innovation: Technology, Market, and Complexity, 6 (3): 91. https://dx.doi.org/10.3390/joitmc6030091

Madjid, T., Hajipour, V., Oveisi, S. (2020): IoT-based enterprise resource planning: Challenges, open issues, applications, architecture, and future research directions. Internet of Things, 11: 100262. http://dx.doi.org/10.1016/j.iot.2020.100262.

Mansoureh, M., Maadi, M., Javidnia, M. (2016): Identification of factors influencing building initial trust in e-commerce. Iranian Journal of Management Studies (IJMS), (9) 3: 483-503. http://dx.doi.org/10.22059/IJMS.2016.57482

Masood, T., Sonntag, P. (2020): Industry 4.0: Adoption challenges and benefits for SMEs. Computers in Industry, 121(103261). https://dx.doi.org/10.1016/j.compind.2020.103261

Meier, A., Stormer, H. (2012): eBusiness \& eCommerce; 3. Auflage. Springer-Verlag. Berlin Heidelberg. ISBN: 978-3-642-29801-1 http://dx.doi.org/10.1007/978-3-642-29802-8

Michelberger P. (2001): Vállalati információs rendszerek jövője. INFORMATIKA - A GÁBOR DÉNES FÖISKOLA KÖZLEMÉNYEI, 4 (3): 34-41.

Michelberger P. (2003): Integrált információs rendszerek összehasonlító értékelése. Bólyai Szemle, 12 (1): 88-98.

Møller, C. (2003): ERP II: Next-generation Extended Enterprise Resource Planning in: Proceedings of the Seventh World Multi-Conference on Systemics, Cybernetics and Informatics.

Moreira, J., Carvalho, A., Horvath T. (2018): A General Introduction to Data Analytics. John Wiley \& Sons, Hoboken (USA). ISBN: 978-1-119-29626-3

Mulesoft (N. A.): Evolution of SOA How organizations develop agile SOA to rein in IT costs and secure competitive advantage. $<$ https://immagic.com/eLibrary/ARCHIVES/GENERAL/MULES_US/SOA-whitepaper.pdf> (2020. 08. 30.)

Müller, F., Jaeger, D., Hanewinkel, M. (2019): Digitization in wood supply - A review on how Industry 4.0 will change the forest value chain. Computers and Electronics in Agriculture, 162 (4): 206-218. https://dx.doi.org/10.1016/j.compag.2019.04.002

Nagy J., Oláh J., Erdei E., Domicián M., Popp J. (2018): The Role and Impact of Industry 4.0 and the Internet of Things on the Business Strategy of the Value Chain-The Case of Hungary. Sustainability, $10 \quad$ (10): $\quad 3491 . \quad$ https://dx.doi.org/10.3390/su10103491. $<$ https://www.mdpi.com/2071-1050/10/10/3491/pdf> (2021. 01. 24.)

Oliveira, T., Martins, M. F. (2011): Literature Review of Information Technology Adoption Models at Firm Level. The Electronic Journal of Information Systems Evaluation, 14 (1): 110-121. https://dx.doi.org/10.12691/ajis-3-2-3

Pajkossy P., Simor P., Szendi I., Racsmány M. (2015): Hungarian Validation of the Penn State Worry Questionnaire (PSWQ) - Comparing Latent Models with One or Two Method Factors Using both Paper-pencil and Online Versions of the PSWQ. European Journal of Psychological Assessment, 31 (3): 159-165. https://dx.doi.org/10.1027/1015-5759/a000221.

Park, J., Hong, C., Yeo, S., Kim, T. (2008): IT Security Strategies for SME's. International Journal of Software Engineering and Its Applications, 2 (3): 91-98. 
Pereira, M. C., Sousa, P. (2015): Enterprise Architecture: Business and IT Alignment“ in: ACM symposium on applied computing, Santa Fe, NM, USA (2005). 1344-1345. https://dx.doi.org/10.1145/1066677.1066980.

Porter, M. E. (1985): "Competitive Advantage: Creating and Sustaining Superior Performance". Free Press, New York (USA). ISBN: 9780029250907

Porter, M. E.., Magretta, J. Kramer, R. M. (2014): Strategy and Competition: The Porter Collection (3 Items). Harvard Business Review Press, Boston (USA) ISBN: 9781625277947

Quist-Aphetsi, K., Kayode, A. I. (2013): Using SOA with Web Services for effective data integration of Enterprise Pharmaceutical Information Systems. arXiv:1307.8179. $<$ https://arxiv.org/pdf/1307.8179> (2021. 01. 24.)

Ramundo, L., Taisch, M., Terzi, S. (2016): State of the art of technology in the food sector value chain towards the IoT In: 2016 IEEE 2nd International Forum on Research and Technologies for Society and Industry Leveraging a better tomorrow (RTSI). ISBN: 978-1-5090-1131-5. 1-6. http://dx.doi.org/10.1109/RTSI.2016.7740612.

Rikhardsson, P., Yigitbasioglu O. (2018): Business intelligence \& analytics in management accounting research: Status and future focus. International Journal of Accounting Information Systems, 19: 37-58. https://doi.org/10.1016/j.accinf.2018.03.001.

Rygielski C., Wang, J., Yen, D. C. Yen (2002): Data mining techniques for customer relationship management. Technology in Society, 24 (4): 483-502. https://dx.doi.org/10.1016/S0160791X(02)00038-6

Schreiber, J. B., Frances, K., King, S. J., Amaury, N., Barlow, E. A. (2014): Reporting Structural Equation Modeling and Confirmatory Factor Analysis Results: A Review. The Journal of Educational Research, 99 (6): 323-338. https://dx.doi.org/10.3200/JOER.99.6.323-338

Sousa, P., Caetano, A., Vasconcelos, A., Pereira, C., Tribolet, J. (2010): Enterprise Architecture Modeling with the Unified Modeling Language In Khosrow-Pour, M. (ed): Business Information Systems: Concepts, Methodologies, Tools and Applications, Information Resources Management Association Hersey - New York (USA). 978-1615209699. 719-742. doi: http://dx.doi.org/10.4018/978-1-61520-969-9.ch045

Tamandeh, S. H. (2016): The effect of business intelligence on management accounting information system. European Online Journal of Natural and Social Sciences, 5 (1): 190-199.

Tarute, A., Gatautis, R. (2014): ICT Impact on SMEs Performance. Procedia-Social and Behavioral Sciences, 110: 1218-1225. https://dx.doi.org/10.1016/j.sbspro.2013.12.968.

Teittinen, H., Pellinen, J., Järvenpää, M. (2013): ERP in action - Challenges and benefits for management control in SME context. International Journal of Accounting Information Systems, 14 (4): 278-296. https://dx.doi.org/10.1016/j.accinf.2012.03.004

Themistocleous, M., Irani, Z., O'Keefe, R. M. (2001): ERP and application integration: Exploratory survey. Business Process Management Journal, 7 (3): 195-204: http://dx.doi.org/10.1108/14637150110392656

Tiemeyer, E. (2020): Handbuch IT-Management Konzepte, Methoden, Lösungen und Arbeitshilfen für die Praxis. Der Carl Hanser Verlag, München. ISBN: 978-3446461840

Tsironis, L. K., Gotzamani, K. D., Mastos, T. D., (2017): e-Business critical success factors: toward the development of an integrated success model. Business Process Management Journal, 23 (5): 874-896. https://dx.doi.org/10.1108/BPMJ-02-2016-0030

Yilmaz, K. G., Gungordu, A., Ayci, A., Yumusak, T. (2016): E-Commerce Adoption as a Predictor of the Perceived Strategic Value of E-Commerce among E-Commerce Adopter SMEs in Turkey. International Journal of Managerial Studies and Research, 4 (3): 35-43

Yahaya, Y. Gunasekaranb, A., Abthorpec, M. S. (2004): Enterprise information systems project implementation: A case study of ERP in Rolls-Royce. International. Journal. Production Economics, 87 (3): 251-266. https://dx.doi.org/10.1016/j.ijpe.2003.10.004 